\title{
Landscape-related variation in the diet composition of the common buzzard (Buteo buteo) in Belarus
}

\author{
Vplyv krajinnej štruktúry na variabilitu zloženia potravy myšiaka lesného (Buteo buteo) \\ v Bielorusku
}

\author{
Anna A. SIDOROVICH, Vladimir V. IVANOVSKIJ, Vadim E. SIDOROVICH \& Irina A. SOLOVEJ
}

\begin{abstract}
We examined common buzzard (Buteo buteo) feeding patterns in landscapes with different habitat structure in Belarus. A total of 561 pellets and prey remains were sampled in 1998-2012 from which 1065 prey and other food items were identified. Effects of habitat structure on buzzard diet composition were investigated using correlation analysis. The most abundant group in buzzards' diets were small rodents (49-80\% of the biomass consumed), followed by other mammals and birds. Reptiles, anurans, fish and invertebrates constituted the rest. Proportions of all food items varied greatly between landscapes. The mean-weighted body mass of vertebrate prey hunted by common buzzards in different landscapes ranged from 107 to 244 g, constituting on average $180 \mathrm{~g}$. Among small rodents, voles of the genus Microtus were hunted selectively. The food niche breadth was directly proportional to the amount of forest habitat. With increasing amount of forest habitat, the proportion of Microtus voles in buzzards' diets decreased and the proportions of other food items grew. These findings confirm the majority of previous results indicating feeding opportunism of the common buzzard. Our investigation enables better understanding of predator-prey interactions and the prey choice of the common buzzard in Belarus.
\end{abstract}

Abstrakt: V Bielorusku sme študovali charakter potravy myšiaka lesného (Buteo buteo) v krajine s rôznou štruktúrou habitatov. V rokoch 1998 až 2012 bolo zozbieraných 561 vývržkov a zvyškov koristi, v ktorých sa identifikovalo 1065 kusov koristi a iných zvyškov potravy. Vplyv štruktúry habitatov na zloženie potravy myšiaka bol zist’ovaný pomocou korelačnej analýzy. Najpočetnejšiu skupinu koristi v potrave myšiaka tvorili drobné hlodavce (49 - 80 \% skonzumovanej biomasy) nasledované inými cicavcami a vtákmi. Plazy, žaby, ryby a bezstavovce tvorili jej zvyšok. Podiel zložiek potravy značne varíruje s ohl'adom na charakter krajiny. Priemerná telesná hmotnost' koristi myšiaka lesného spomedzi stavovcov v rôznom prostredí dosahovala od 107 do 244 g, priemerne 180 g. Spomedzi drobných hlodavcov boli hraboše rodu Microtus lovené selektívne. Š́rka potravnej niky bola priamo úmerná množstvu lesného habitatu v krajine. So zvyšovaním podielu lesa klesal podiel hrabošov rodu Microtus v potrave myšiaka a podiel inej potravy rástol. Tieto zistenia potvrdzujú výsledky väčšiny doterajších štúdií indikujúcich potravný oportunizmus myšiaka lesného. Náš výskum umožňuje lepšie pochopit' interakcie medzi dravcom a korist’ou a výber koristi myšiakom v Bielorusku.

Key words: Buteo buteo, feeding, habitat structure, small rodents, Belarus

\begin{abstract}
Anna A. Sidorovich, National Academy of Sciences of Belarus, Scientific and Practical Center for Bioresources, Sector of Ecological Impact Assessment of Environment Alterations, Akademicheskaya Str. 27, BY-220072 Minsk, Belarus. E-mail: sidorovich.ecofox@gmail.com (corresponding author).

Vladimir V. Ivanovskij, Vitebsk State University named after P.M. Masherov, Faculty of Biology, Department of Ecology and Nature Protection, Moscow Ave. 33, BY-210038 Vitebsk, Belarus. E-mail: ivanovski@tut.by.

Vadim E. Sidorovich, National Academy of Sciences of Belarus, Scientific and Practical Center for Biological Resources, Laboratory of Theriology, Akademicheskaya Str. 27, BY-220072 Minsk, Belarus. E-mail: vadim.sidorovich@gmail.com.

Irina A. Solovej, National Academy of Sciences of Belarus, Scientific and Practical Center for Biological Resources, Laboratory of Theriology, Akademicheskaya Str. 27, BY-220072 Minsk, Belarus. E-mail: soloveji@tut.by.
\end{abstract}

Acknowledgments: The authors are grateful to Dr. Benjamín Jarčuška, Dr. Luis Tapia, Dr. Ján Obuch and two anonymous reviewers for their helpful and critical comments.

\section{Introduction}

The common buzzard (Buteo buteo) is known to be a generalist predator that feeds on a wide range of prey, mainly small and medium-sized mammals and birds, but also on other vertebrate and invertebrate animals (for example, Dementjev 1951, Cramp \& Simmons 1980, Shalabaev \& Kassal 2010). In Belarus, there have been a few local investigations on the diet composition 
of the common buzzard (Golodushko 1965, Sidorovich 2011). However, the mechanisms of prey selection by a such versatile predator should be studied more precisely to reveal the whole variety of feeding patterns in changeable conditions. The above-mentioned studies show that in Paazerje and Białowieża Forest small mammals, birds, reptiles and amphibians were consumed by the predator in almost equal proportions (Golodushko 1965, Sidorovich 2011). In most European countries, common buzzards prefer to prey on small rodents (Goszczyński \& Piłatowski 1986, Selås et al. 2007, Butet et al. 2010), whereas in southern Europe, they have more diversified and changeable diets (Bustamante 1985, Mañosa \& Pedro 1992, Mañosa \& Cordero 1992, Zuberogoitia et al. 2006, Tapia at el. 2007).

In this study we try to reveal which type of food is a result of selective predation and which is a reflection of the difference in its abundance. Thus, the aim was to analyze the diet composition and feeding habits of the common buzzard in different landscapes of Belarus in relation to the habitat structure and abundance of small rodents.

\section{Material and methods}

Data were obtained in 1998-2012 in northern and central parts of Belarus. The territory lies in the conifer- ous/small-leaved European forest zone. The chosen five study areas differed greatly in their ecological landscape structure, reflecting the variability of landscapes of the region (Fig. 1, Tab. 1). The first study area, called the Chyrvony Bor terrain, is situated in the Rassony and Verkhniadzvinsk districts of the Vitebsk region $\left(55^{\circ} 58^{\prime}\right.$ $\left.\mathrm{N}, 28^{\circ} 22^{\prime} \mathrm{E}\right)$. It consists of semi-natural, completely forest covered landscape dominated by ecologicallypoor pine stands. The second study area is a forested area in the upper reaches of the Lovat' river (the Lovat' terrain), in the Haradok district of the Vitsebsk region $\left(55^{\circ} 46^{\prime} \mathrm{N}, 30^{\circ} 15^{\prime} \mathrm{E}\right)$. There is much clay in the surface ground deposits, resulting in good water supply and abundant trace elements producing rich soil, so habitats with high plant species diversity and productivity dominate. The next study area, the Nalibotskaya Pushcha terrain, is a wide ranging woodland of the boreal nemoral type in the central-western part of Belarus (Valozhyn and Staubtsy districts of the Minsk region, and Iuje and Navahradak districts of the Hrodna region, $53^{\circ} 55^{\prime} \mathrm{N}, 26^{\circ} 20^{\prime} \mathrm{E}$ ). Various forest habitats make up about $88 \%$ of the terrain. Large open grasslands on abandoned peat-moors spread through the forest. Many of the forest rivers were canalized in 1960s-1980s, and nowadays beavers have created numbers of small ponds from 3 to 29 per $1 \mathrm{~km}^{2}$. The fourth study area, called the Valozhyn terrain, is an extended rural landscape adja-

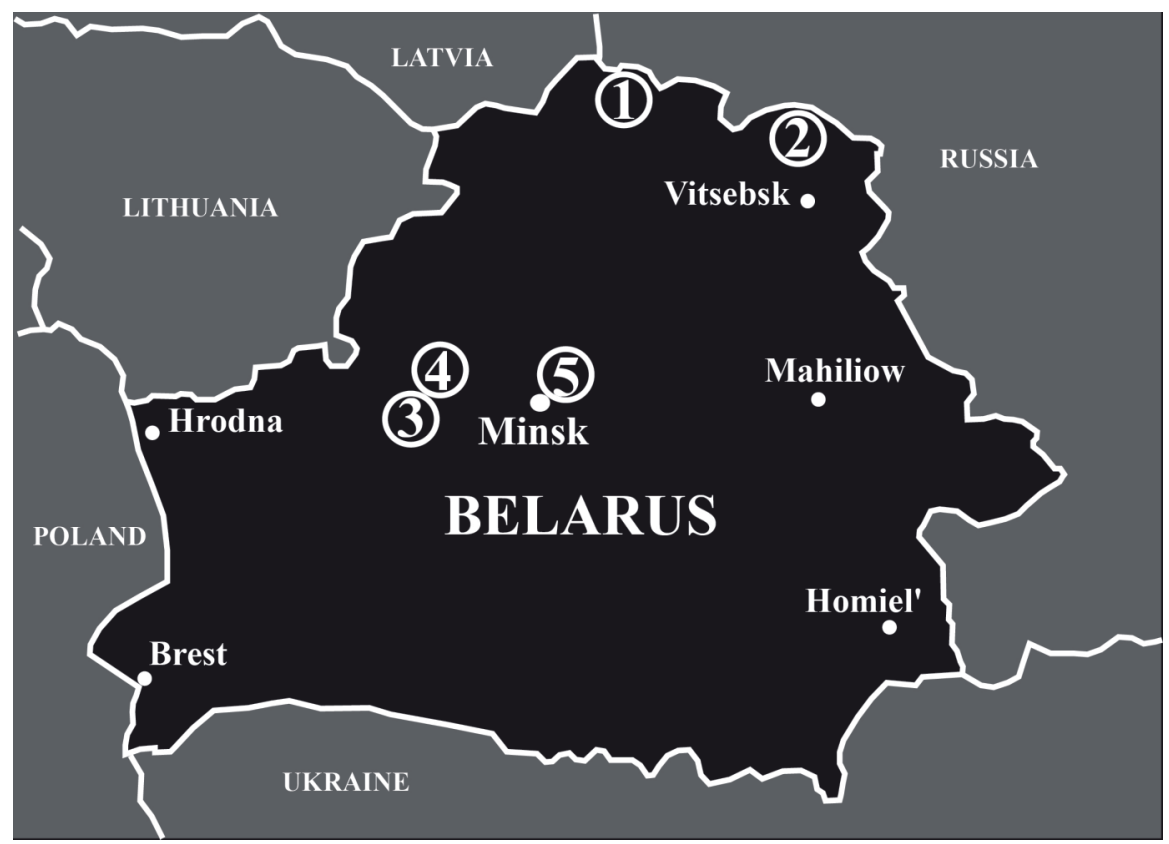

Fig. 1. Location of study areas in Belarus.

Obr. 1. Študované územia v Bielorusku 
Slovak Raptor Journal 2016, 10: 65-74. DOI: 10.1515/srj-2016-0006.

(C) Raptor Protection of Slovakia (RPS)

Tab. 1. Landscape and habitat-related differences between the five study areas in Belarus.

Tab. 1. Krajinné a habitatové rozdiely medzi piatimi študovanými územiami v Bielorusku.

\begin{tabular}{|c|c|c|c|c|c|}
\hline \multirow[b]{2}{*}{ habitat (\%) } & \multicolumn{5}{|c|}{ study areas / študované územia } \\
\hline & Chyrvony Bor & Lovat' & $\begin{array}{l}\text { Nalibotskaya } \\
\text { Pushcha }\end{array}$ & Valozhyn & $\begin{array}{l}\text { Prylepski } \\
\text { Zakaznik }\end{array}$ \\
\hline dry land pine stands of any age ${ }^{1}$ & 46 & 10 & 17 & 1 & 4 \\
\hline spruce forests older than 60 years ${ }^{2}$ & 6 & 23 & 7 & 2 & 30 \\
\hline succession woods dominated by small-leaved trees ${ }^{3}$ & 6 & 14 & 17 & 2 & 6 \\
\hline raised bogs with suppressed pine stands ${ }^{4}$ & 14 & 5 & 5 & - & 1 \\
\hline black alder swamps ${ }^{5}$ & 12 & 16 & 30 & - & - \\
\hline broad-leaved forests older than 60 years ${ }^{6}$ & - & - & 5 & - & - \\
\hline open grassy marshes ${ }^{7}$ & 2 & 9 & 4 & - & - \\
\hline dry meadows ${ }^{8}$ & 4 & 10 & 7 & 5 & 2 \\
\hline clear cuts up to 7 years ${ }^{9}$ & 2 & 9 & 6 & - & 30 \\
\hline agricultural fields ${ }^{10}$ & 3 & 1 & 1 & 80 & 13 \\
\hline villages and towns ${ }^{11}$ & $<1$ & $<1$ & $<1$ & 10 & 13 \\
\hline aquatic ecosystems ${ }^{12}$ & 5 & 3 & 1 & - & - \\
\hline total area / celková výmera $\left(\mathrm{km}^{2}\right)$ & 100 & 300 & 1500 & 110 & 48 \\
\hline
\end{tabular}

Habitaty: ${ }^{1}$ boriny rôzneho veku na suchých stanovištiach, ${ }^{2}$ smrečiny staršie než 60 rokov, ${ }^{3}$ sukcesné lesy s dominujúcimi drobnolistými drevinami (brezové a osikové), ${ }^{4}$ rašeliniská s potlačenými borinami, ${ }^{5}$ slatiny jelše lepkavej, ${ }^{6}$ porasty širokolistých drevín staršie než 60 rokov, ${ }^{7}$ otvorené trávnaté mokrade, ${ }^{8}$ suché lúky, ${ }^{9}$ holoruby do 7 r., ${ }^{10}$ polia, ${ }^{11}$ obce a mestá, ${ }^{12}$ vodné plochy.

cent to the Nalibotskaya Pushcha terrain $\left(54^{\circ} 02^{\prime} \mathrm{N}\right.$, $\left.26^{\circ} 30^{\prime} \mathrm{E}\right)$. There is a dense drainage canal network across the whole territory. The last study area, the Prylepski Zakaznik terrain (Minsk district, Minsk region, $53^{\circ} 54^{\prime} \mathrm{N}, 27^{\circ} 49^{\prime} \mathrm{E}$ ), is a relatively large fragment of young coniferous forest that is surrounded by suburban and rural areas.

The hilly relief of the northern part of Belarus originated from the last Menapian glaciation, and the mostly plain relief of the central part of Belarus is preserved from the earlier Elsterian glaciation (Matveev et al. 1988). The climate is humid continental. Winters are

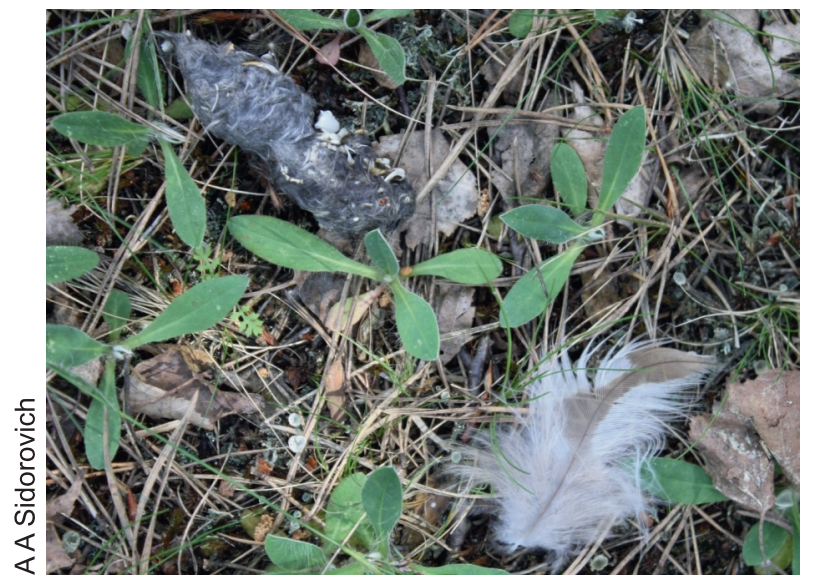

Fig. 2. A pellet of the common buzzard under the nest. Obr. 2. Vývržok myšiaka lesného pod hniezdom. variable with alternating periods of severe frosts below $-20^{\circ} \mathrm{C}$ and thaws lasting for some weeks. Usually snow cover persists for at least 1.5-2 months, with a maximum depth of 30-90 cm.

Data on the food of the common buzzard were obtained using the following methods:

1) Analysis of pellets (Fig. 2). These were gathered either under roosting sites near the known nests as well as under the nests themselves, or under roosting sites well known from visual observation.

2) Analysis of prey brought to the nest (Fig. 3).

A total of 561 pellets and prey remains were

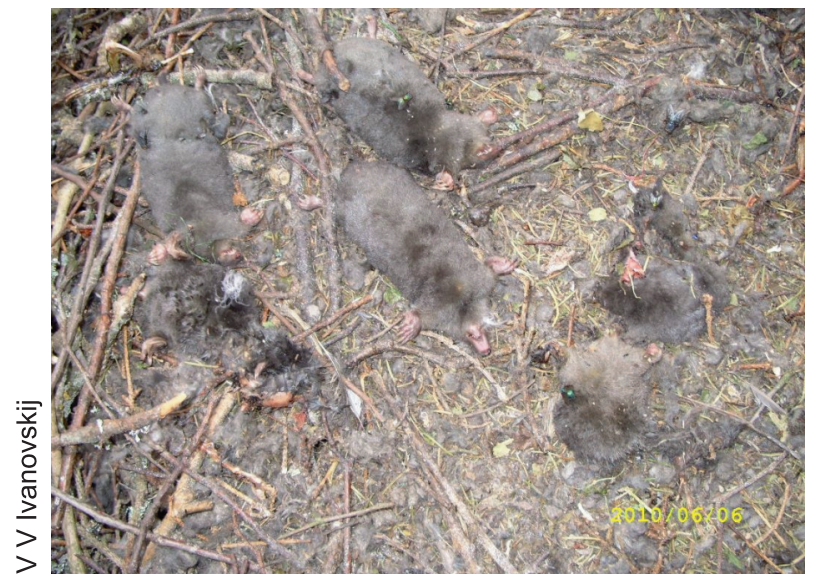

Fig. 3. Prey items (Talpa europaea) in the common buzzard nest.

Obr. 3. Korist' (Talpa europaea) v hniezde myšiaka lesného. 
sampled in May-September 1998-2012 from which 1065 prey and other food items were identified. The material collected was analyzed as follows. The hair piles of mammalian prey from pellets and remains were microscopically examined using cross sections (Debrot et al. 1982, Teerink 1991). Small mammal identification was done by identification of their skulls and skull remains recovered from pellets (Pucek 1981). The number of specimens of the same small mammal species in a pellet was estimated from the number of similar skeletal remains and using known weights of hair coat for different species (Sidorovich 2015). Other components were analyzed using the published keys of feathers and bones of birds, bones of amphibians, bones and skin scales of reptiles (Böhme 1977, März 1987, Brown et al. 1999). Insects were distinguished by the remains of the exoskeleton.

To obtain the percentage of food biomass consumed (hereafter, $\% \mathrm{Bc}$ ), the numbers of prey individuals were multiplied by the mean body mass of that prey (Pucek 1981, Sidorovich 2011). If the weight of a given prey or another food item (in the case of carrion consumption) was higher than the weight of average daily food intake of the common buzzard, we used the latter value in the dietary calculations. According to Cramp (1980) this averages $120 \mathrm{~g}$ per day.

The mean body mass of prey (M) was calculated in the following way:

$$
\mathrm{M}=\sum\left(\mathrm{m}_{\mathrm{i}} \times \mathrm{p}_{\mathrm{i}}\right)
$$

where $m_{i}$ - mean weight of individuals of the prey species i brought by buzzards to checked nests (for medium-sized prey) or mean weight of individuals from living populations for small mammals occurring in pellets only, $p_{i}-$ portion of the prey species $\mathrm{i}$ in the buzzards' diets.

The abundance of small rodents was estimated each year in the period July-October (post-reproductive period) by snap trapping, which is the most efficient trapping technique for most small rodent species (Wiener \& Smith 1972). Fried bread was used as bait in all types of habitats. Depending on habitat size, 20 to 35 snap-traps were set at approximately $5 \mathrm{~m}$ distances for three days (checked daily). Each year we performed a census of small rodents in a variety of the main habitat types (pine forests, spruce forests, black alder swamps, clear-cuts, open grassy marshes, dry meadows, and agricultural fields) that together composed more than $90 \%$ of the study areas. In a total, approximately 14,000 snap-trap observation nights were performed.

Dietary diversity (trophic niche breadth) was compared using the Levins' index B (Levins 1968):

$$
\mathrm{B}=1 / \sum \mathrm{p}_{\mathrm{i}}^{2}
$$

where $p_{i}$ - the fraction food item i forms of the total biomass consumed by common buzzards. The calculation was performed for 23 food categories, so the B index varies from 1 (the narrowest niche) to 23 (the broadest niche possible). Morisita's index $\mathrm{C}_{\mathrm{H}}$ (simplified, after Krebs 1999) was used to compare diets:

$$
\mathrm{C}_{\mathrm{H}}=\left(2 \sum_{\mathrm{i}}^{\mathrm{n}} \mathrm{p}_{\mathrm{ij}} \mathrm{p}_{\mathrm{ik}}\right) /\left(\sum_{\mathrm{i}}^{\mathrm{n}} \mathrm{p}_{\mathrm{ij}}{ }^{2}+\sum_{\mathrm{i}}^{\mathrm{n}} \mathrm{p}_{\mathrm{ik}}{ }^{2}\right)
$$

where $p_{i j}$ - the fraction food item i forms of the total biomass consumed by common buzzards in the study area $\mathrm{j} ; p_{i k}$ - the fraction food item $\mathrm{i}$ forms of the total biomass consumed by common buzzards in the study area $\mathrm{k} ; i=1,2,3, \ldots, n ; n$-total number of food items. The index varies between 0 (exclusive niches) and 1 (complete overlap). Based on the value of this index, we formally fixed three levels of dietary overlap, with $0-0.33$ representing small overlap, $0.34-0.66$ as moderate overlap and $0.67-1.0$ as large overlap. To assess the common buzzard's preference for a particular rodent or bird species (or species group), Ivlev's electivity index D (after Jacobs 1974) was calculated:

$$
\mathrm{D}=(\mathrm{r}-\mathrm{p}) /(\mathrm{r}+\mathrm{p}-2 \mathrm{rp})
$$

where $r$-proportion of the prey species in the common buzzard diet, $p$ - proportion of the prey species in the living community. This index can range from -1 (total avoidance of a species) through 0 (selection proportional to occurrence) to 1 (maximum positive selection).

Variation in the dietary data obtained was assessed using the coefficient of variation (hereafter CV). Spearman's rank correlation coefficients $\left(\mathrm{r}_{\mathrm{s}}\right)$ between proportions of different food items in common buzzard diets and landscape parameters as well as abundance of different small rodent groups were computed.

Most of the statistical calculations were carried out using ASPID/GT software (Grigyantz 1993). The STATISTICA 8.0 software (StatSoft, USA) was also used according to the recommendations given by Sokal \& Rohlf (1995). 
Tab. 2. Diet composition of the common buzzard expressed as percentages of the biomass consumed in different landscapes of Belarus, 1998-2012, $\mathrm{n}=1065$.

Tab. 2. Zloženie potravy myšiaka lesného $v$ percentách skonzumovanej potravy $\vee$ rôznych územiach Bieloruska; $1998-2012, n=$ 1065.

\begin{tabular}{|c|c|c|c|c|c|c|}
\hline \multirow[t]{2}{*}{ taxa / taxón } & \multicolumn{3}{|c|}{ study areas / študované územia } & \multirow[b]{2}{*}{ Valozhyn } & \multirow[b]{2}{*}{$\begin{array}{l}\text { Prylepski } \\
\text { Zakaznik }\end{array}$} & \multirow[t]{2}{*}{$\sum$} \\
\hline & Chyrv & or Lovat' & $\begin{array}{l}\text { Nalibotskaya } \\
\text { Pushcha }\end{array}$ & & & \\
\hline Orthoptera & - & - & 0.3 & 0.1 & - & 0.1 \\
\hline Coleoptera & 0.3 & 0.1 & 0.1 & 0.1 & 0.2 & 0.2 \\
\hline Perciformes & - & 0.1 & - & - & - & $>0.1$ \\
\hline Cypriniformes & 0.7 & 0.5 & - & - & - & 0.2 \\
\hline Esox lucius & - & 0.1 & - & - & - & $>0.1$ \\
\hline Pelophylax sp. & - & 2.3 & - & - & - & 0.5 \\
\hline Rana sp. & 2.0 & 6.4 & 1.5 & 1.5 & 2.7 & 2.8 \\
\hline Bufo sp. & 5.1 & 6.1 & 11.2 & - & - & 4.5 \\
\hline Natrix natrix & - & 2.7 & 9.0 & - & - & 2.3 \\
\hline Vipera berus & - & - & 1.1 & - & - & 0.2 \\
\hline Lacerta sp. & - & 0.7 & 1.1 & - & 0.8 & 0.5 \\
\hline Anguis fragilis & - & 0.6 & 0.3 & - & - & 0.2 \\
\hline Sorex sp. & 0.4 & 0.4 & - & - & - & 0.2 \\
\hline Talpa europaea & 8.3 & 4.0 & 0.9 & 3.1 & 12.5 & 5.8 \\
\hline Erinaceus sp. & - & 1.3 & - & 2.1 & - & 0.7 \\
\hline Myodes glareolus & 12.7 & 6.7 & 22.8 & 1.3 & 6.2 & 9.9 \\
\hline Sylvaemus sp. & 2.4 & 1.5 & 3.0 & 1.1 & 1.0 & 1.8 \\
\hline Apodemus agrarius & - & - & - & 7.2 & 0.8 & 1.6 \\
\hline Microtus sp. & 16.2 & 14.1 & 30.1 & 44.5 & 19.4 & 24.9 \\
\hline Arvicola terrestris & 5.5 & 6.7 & - & 4.1 & - & 3.3 \\
\hline Micromys minutus & - & - & 0.1 & 0.1 & - & $>0.1$ \\
\hline Dryomys nitedula & 2.5 & - & - & - & - & 0.5 \\
\hline Rattus norvegicus & - & - & 2.0 & - & - & 0.4 \\
\hline Sciurus vulgaris & 5.5 & 1.3 & - & - & 7.4 & 2.8 \\
\hline Lepus sp. & 11.4 & 5.4 & 4.4 & 5.6 & - & 5.4 \\
\hline Vulpes vulpes & 2.2 & - & - & - & - & 0.4 \\
\hline Mustela nivalis & - & - & - & 1.2 & - & 0.2 \\
\hline Felis silvestris catus & - & 4.7 & - & 2.1 & 22.3 & 5.8 \\
\hline Cervidae & - & 4.0 & - & 5.5 & - & 1.9 \\
\hline Sus scrofa & - & 1.3 & - & 0.7 & - & 0.4 \\
\hline Anthus trivialis & - & 0.2 & - & - & - & $>0.1$ \\
\hline Motacilla alba & - & 2.3 & - & - & - & 0.5 \\
\hline Turdus sp. & 2.2 & 8.5 & 2.7 & - & 19.1 & 6.5 \\
\hline Emberiza citrinella & - & - & 0.3 & - & - & 0.1 \\
\hline Fringilla coelebs & 0.6 & 6.1 & 0.5 & - & 0.5 & 1.5 \\
\hline Sturnus vulgaris & - & 0.3 & 0.5 & 2.1 & - & 0.6 \\
\hline Alauda sp. & - & 0.7 & 0.5 & 3.1 & 2.2 & 1.3 \\
\hline Parus sp. & - & 1.2 & - & - & 1.2 & 0.5 \\
\hline Poecile sp. & - & 0.3 & - & - & - & 0.1 \\
\hline Garrulus glandarius & 5.5 & 9.4 & 5.1 & - & 3.7 & 4.7 \\
\hline Pica pica & - & - & - & 2.1 & - & 0.4 \\
\hline Scolopax rusticola & 5.5 & - & - & - & - & 1.1 \\
\hline Strix aluco & - & - & 0.7 & - & - & 0.1 \\
\hline Lyrurux tetrix & 1.0 & - & - & - & - & 0.2 \\
\hline Bonasa bonasia & 10.0 & - & 1.8 & - & - & 2.4 \\
\hline $\begin{array}{l}\text { Perdix perdix } \\
\text { mean body mass of mammalian prey }(\mathrm{g})\end{array}$ & - & - & - & 12.4 & - & 2.5 \\
\hline $\begin{array}{l}\text { priemerná telesná hmotnost' cicavčej koristi } \\
\text { mean body mass of bird prey }(\mathrm{g}) /\end{array}$ & 298.0 & 275.2 & 109.9 & 162.1 & 300.9 & 226.4 \\
\hline $\begin{array}{l}\text { priemerná telesná hmotnost' vtáčej koristi } \\
\text { mean body mass of vertebrate prey }(\mathrm{g}) /\end{array}$ & 171.3 & 75.5 & 142.2 & 157.5 & 65.2 & 114.3 \\
\hline $\begin{array}{l}\text { priem. telesná hmotnost' stavovcov } v \text { koristi } \\
\text { Levins' index }(B) \text { of food niche breadth / }\end{array}$ & 244.2 & 164.9 & 106.9 & 158.1 & 227.2 & 179.6 \\
\hline $\begin{array}{l}\text { Levinov index }(B) \text { šírky potravnej niky } \\
\text { number of prey and other food items / }\end{array}$ & 11.1 & 14.8 & 5.9 & 4.3 & 6.6 & 8.6 \\
\hline počet koristi a iných zvyškov potravy & 96 & 553 & 179 & 151 & 86 & 106569 \\
\hline
\end{tabular}




\section{Results}

The range of prey consumed by the common buzzard in different landscapes of Belarus was quite broad (Tab. 2). Levins' index B varied from 4.3 to 14.8 , with an average value of 8.6 . The predator however predominantly consumed mammalian prey which comprised the bulk of the diet (from 51.4 to $78.6 \% \mathrm{Bc}$, on average $66.1 \%$ $\mathrm{Bc}$ ). Birds were also frequently eaten (from 12.1 to $29.0 \% \mathrm{Bc}$, on average $22.5 \% \mathrm{Bc}$ ). Amphibians, reptilians and fish made up most of the remainder (altogether from 1.5 to $24.2 \% \mathrm{Bc}$, on average $11.3 \% \mathrm{Bc}$ ). Proportions of food categories varied greatly between different landscapes (for mammalian prey $\mathrm{CV}$ varied between 63.0-264.4, mean 126.7\%; for avian prey 78.9-380.0, mean $181.8 \%$; for other prey $68.4-170.0 \%$, mean $126.9 \%)$.

Common buzzards hunted vertebrate prey in the size range from $7 \mathrm{~g}$ to $500 \mathrm{~g}$. The mean-weighted body mass of vertebrate prey in different landscapes ranged from $106.9 \mathrm{~g}$ in the Nalibotskaya Pushcha terrain to $244.2 \mathrm{~g}$ in the Chyrvony Bor terrain, and on average it was $179.6 \mathrm{~g}$ (Tab. 2). Mammalian prey items were on average two times heavier than bird prey. Regarding mammalian prey, voles of the genus Microtus and the bank vole (Myodes glareolus) made up a large proportion of the diet (Tab. 2). Hares (Lepus timidus and L. europaeus) and the common mole (Talpa europaea) were also of great importance. The species composition was landscape-related. For instance, in the Pryliepski Zakaznik terrain (forest-suburban mosaic landscape), young domestic cats (Felis silvestris catus) were frequently caught by common buzzards, constituted $22.3 \%$ Bc. In the Valozhyn terrain with a large proportion of rural habitats, the common vole (Microtus cf. arvalis) was frequently preyed upon by the predator $(39.5 \% \mathrm{Bc})$.
The species composition of small rodents captured by buzzards was compared with the rodent community living in the study areas (Tab. 3). The data indicate that buzzards captured Microtus voles more often than would have been expected from their proportion in the community. The selectivity index $\mathrm{D}$ for this prey was positive and lay between 0.56 to 0.92 (Tab. 4). Forest rodents (bank voles and Sylvaemus mice) were taken by raptors in lower proportions than their availability.

The species composition of bird prey also shows very broad variation. Depending on the study area, the predominant group in the common buzzard diet was thrushes of the genus Turdus, the Eurasian jay (Garrulus glandarius) or tetraonids. Proportions of other bird species were small, although they comprised in total from 2.5 to $11.1 \% \mathrm{Bc}$ (on average 5.\% Bc). Most of the birds caught by the raptor were fledglings.

Correlation analysis revealed the following features. In landscapes with a bigger proportion of open habitats, a higher percentage of Microtus vole biomass in the buzzard diets was found $\left(\mathrm{r}_{\mathrm{s}}=0.82, \mathrm{P}<0.01 ; \mathrm{R}^{2}=0.92\right.$, $\mathrm{P}<0.05$ ), and the range of food resources used by the predator was narrower there $\left(\mathrm{r}_{\mathrm{s}}=-0.73, \mathrm{P}<0.01 ; \mathrm{R}^{2}=\right.$ $0.67, \mathrm{P}<0.05)$. Conversely, the food niche breadth was directly proportional to the amount of forest habitat in the landscape structure $\left(\mathrm{r}_{\mathrm{s}}=0.78, \mathrm{P}<0.01 ; \mathrm{R}^{2}=0.66, \mathrm{P}\right.$ $<0.05$ ). With increasing amounts of forest habitat, consumption of Microtus voles decreased $\left(\mathrm{r}_{\mathrm{s}}=0.83, \mathrm{P}<\right.$ $\left.0.01 ; \mathrm{R}^{2}=0.78, \mathrm{P}<0.05\right)$, whereas consumption of the following food categories grew: toads $\left(\mathrm{r}_{\mathrm{s}}=0.87, \mathrm{P}<\right.$ $\left.0.05 ; \mathrm{R}^{2}=0.83, \mathrm{P}<0.05\right)$, anurans $\left(\mathrm{r}_{\mathrm{s}}=0.96, \mathrm{P}<0.01\right.$; $\left.\mathrm{R}^{2}=0.83, \mathrm{P}<0.05\right)$, snakes $\left(\mathrm{r}_{\mathrm{s}}=0.87, \mathrm{P}<0.01 ; \mathrm{R}^{2}=\right.$ $0.89, \mathrm{P}<0.05)$, lizards $\left(\mathrm{r}_{\mathrm{s}}=0.85, \mathrm{P}<0.01 ; \mathrm{R}^{2}=0.85, \mathrm{P}\right.$ $<0.05)$, soricids $\left(\mathrm{r}_{\mathrm{s}}=0.86 ; \mathrm{P}<0.01, \mathrm{R}^{2}=0.67, \mathrm{P}<\right.$ $0.05)$, bank voles $\left(\mathrm{r}_{\mathrm{s}}=0.89, \mathrm{P}<0.01 ; \mathrm{R}^{2}=0.89, \mathrm{P}<\right.$

Tab. 3. Abundance (individuals captured per 100 trap-nights) of small rodent taxa in Belarus, 1998-2013.

Tab. 3. Početnost' (počet jedincov chytených počas 100 pasco-nocí) taxónov drobných hlodavcov v Bielorusku, 1998 - 2013.

\begin{tabular}{|c|c|c|c|c|c|c|}
\hline taxa / taxón & & Chyrvony Bor & Lovat' & $\begin{array}{l}\text { Nalibotskaya } \\
\text { Pushcha }\end{array}$ & Valozhyn & $\begin{array}{l}\text { Prylepski } \\
\text { Zakaznik }\end{array}$ \\
\hline trap-nights (n) / pasco-noci & & 891 & 4392 & 5724 & 507 & 2541 \\
\hline \multirow[t]{2}{*}{ Microtus } & mean $\pm S D$ & $0.3 \pm 0.5$ & $2.0 \pm 2.9$ & $2.2 \pm 5.1$ & $3.5 \pm 5.1$ & $1.0 \pm 1.4$ \\
\hline & $\min -\max$ & $0-2.7$ & $0-14.6$ & $0-25.3$ & $0.3-29.5$ & $0-4.0$ \\
\hline \multirow[t]{2}{*}{ Myodes glareolus } & mean $\pm S D$ & $2.2 \pm 1.9$ & $5.1 \pm 3.7$ & $4.4 \pm 3.0$ & $0.9 \pm 0.3$ & $4.8 \pm 3.9$ \\
\hline & $\min -\max$ & $0-5.6$ & $1.3-34.3$ & $0.4-13.2$ & $0-1.2$ & $0-10.2$ \\
\hline \multirow[t]{2}{*}{ Sylvaemus sp. } & mean $\pm S D$ & $0.8 \pm 2.1$ & $2.3 \pm 2.5$ & $2.4 \pm 2.8$ & $1.8 \pm 0.3$ & $2.7 \pm 1.5$ \\
\hline & $\min -\max$ & $0-6.7$ & $0-9.3$ & $0.1-14.7$ & $0-2.2$ & $0-5.8$ \\
\hline \multirow[t]{2}{*}{ Apodemus agrarius } & mean $\pm S D$ & $0.03 \pm 0.05$ & $0.04 \pm 0.06$ & $0.2 \pm 0.4$ & $14.5 \pm 9.7$ & $1.1 \pm 1.5$ \\
\hline & $\min -\max$ & $0-0.9$ & $0-1.0$ & $0-1.0$ & $2.3-31.4$ & $0-5.0$ \\
\hline \multirow{2}{*}{$\begin{array}{l}\text { other small rodent species / } \\
\text { iné drobné hlodavce }\end{array}$} & mean $\pm S D$ & $0.01 \pm 0.01$ & $0.1 \pm 0.03$ & $0.2 \pm 0.4$ & $2.3 \pm 0.3$ & $1.3 \pm 1.1$ \\
\hline & $\min -\max$ & $0-0.05$ & $0-2.8$ & $0-1.0$ & $0-4.2$ & $0-5.4$ \\
\hline
\end{tabular}




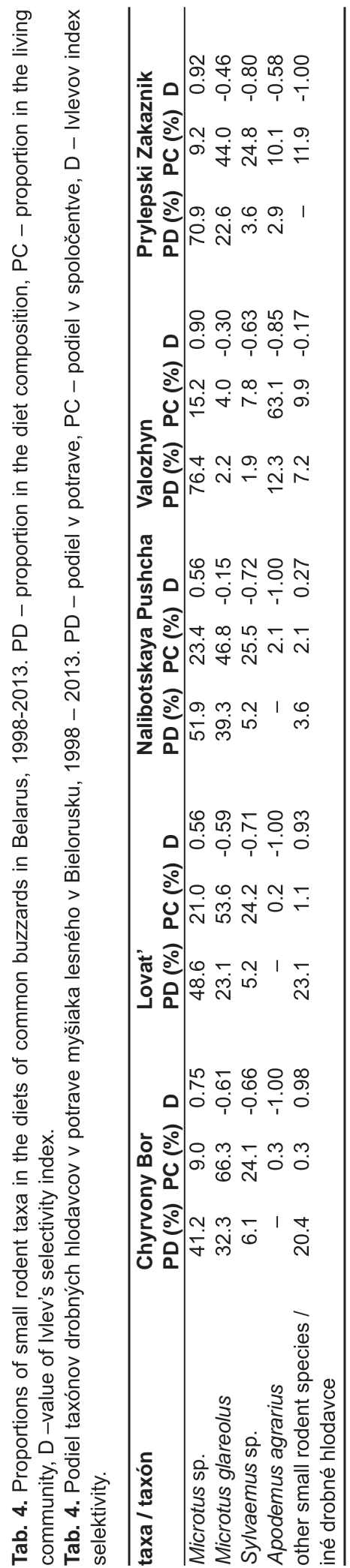

$0.05)$, and Sylvaemus mice $\left(\mathrm{r}_{\mathrm{s}}=0.90, \mathrm{P}<0.01 ; \mathrm{R}^{2}=\right.$ $0.79, \mathrm{P}<0.05)$. Moreover, the consumption of domestic animals correlated with the presence of human settlements $\left(\mathrm{r}_{\mathrm{s}}=0.73 ; \mathrm{P}<0.05 ; \mathrm{R}^{2}=0.74, \mathrm{P}<0.05\right)$ and the consumption of the field-striped mouse correlated with the presence of agricultural fields $-r_{s}=0.89, \mathrm{P}<0.01$; $\left.\mathrm{R}^{2}=0.99, \mathrm{P}<0.01\right)$.

\section{Discussion}

The influence of varying food supply on the diet composition of common buzzards has been shown in many studies. Particular prey choice may be determined by habitat differences (Butet et al. 2010, Graham et al. 1995, Zawadzka 2002, Šotnár \& Obuch 2009), seasonal or multiannual variations in food supply (Sylven 1982, Spidsø \& Selås 1988, Mañosa \& Pedro 1992, Šotnár \& Obuch 2009). Microtus voles in particular with their cyclic population dynamics are the most important prey species in most European countries (Pinowski \& Ryszkowski 1962, Truszkowski 1976, Sylven 1982, Goszczyński \& Piłatowski 1986, Spidsø \& Selås 1988, Zawadzka 2002, Reif et al. 2004, Šotnár \& Obuch 2009). This was also the case in the western parts of Russia (Dementjev 1951, Karyakin 1998, and references therein) and as well as in Ukraine (Redinov 2012).

Data from the UK are quite controversial. Authors from Britain state that European rabbits (Oryctolagus cuniculus) were the primary prey which influenced the diet of the common buzzard there (Moore 1957, Graham et al. 1995). The exception was the period of pandemic myxomatosis, when field voles (M. agrestis) predominated in the predator's diet (Moore 1957, Holdsworth 1971, Cramp \& Simmons 1980). In Ireland in contrast, small rodents are considered to be the main prey (Swann 2011). Only in the northern parts of Ireland, where rodents and other small mammals are scarce, common buzzards mostly preyed on available rabbits and other vertebrate animals (Rooney \& Montgomery 2013).

Completely different findings were obtained in the Polish part of the Białowieża Forest, where birds made up $51-75 \%$ of the biomass consumed by common buzzards. Between-year variation in Microtus abundance was not reflected in the diet of buzzards there (Jędrzejewski et al. 1994). In the Belarusian part of Białowieża Forest amphibians used to be the main food of buzzards and made up $31 \%$ of identified prey individuals (Golodushko 1965). Birds (28\%) and reptiles (21\%) were 
important alternative prey. As noted by the author himself, that study had been conducted during a Microtus vole population crash.

Our study is in good accordance with previous ones confirming the general feeding habits of the common buzzard. However, despite the buzzard's versatility, its preferred food in Belarus was clearly Microtus voles. In different landscapes of Belarus Microtus voles (mainly the common vole and the bank vole) provided the bulk of the common buzzard diets. Other small and mediumsized prey and even invertebrates diversified the diets substantially. The diet composition depended on the proportion of open habitats in the landscape structure where the abundance of Microtus voles was higher, and highly selective predation on these rodent species was revealed. The food niche breadth of the common buzzards varied from relatively medium (4.3, when Microtus voles dominated the diet) to wide (14.8, in ecologically-poor forest terrain). Widening of the trophic niche only when Microtus voles were scarce confirms the alternative prey hypothesis versus non-selective food intake on the assumption of the shared predation hypothesis.

The size of vertebrate prey brought to the nest seems to lie between that of shrews to young cats and can make up from $1 \%$ to $60 \%$ of the predator's body weight. It is interesting to notice that common buzzards sometimes had a quite unusual diet. In our case it was frequent predation upon the domestic cat in the suburban landscape surrounding our Prylepski Zakaznik study area. This most likely reflected the high number of feral cats there, even despite the high availability of small rodents. Intraguild predation is well described among vertebrate predators. Large and medium-sized raptors often kill smaller avian and mammalian predators (Jędrzejewska \& Jędrzejewski 1998, Sergio \& Hiraldo 2008, Sidorovich 2011). This mechanism is not only for energy benefit but rather for elimination of potential competitors.

From our analyses we can conclude that in the conditions of Belarus the common buzzard is a generalist predator with an opportunistic feeding strategy. The diet of this species is variable and reflects the availability of Microtus voles which, in turn, vary in relation to the habitat structure.

\section{References}

Böhme G 1977: Zur Bestimmung quartärer Anuren Europas an Hand von Skelettelementen.
Wissenschaftliche Zeitschrift der HumboldtUniversitat $\mathrm{zu}$ Berlin. MathematischNaturwissenschaftliche Reihe 26: 283-300.

Brown R, Ferguson J \& Lees D 1999: Tracks and signs of the birds of Britain and Europe. Christopher Helm Publishers, London, 232.

Bustamante Díaz JM 1985: limentación del ratonero común (Buteo buteo, L. 1758) en el norte de España [Diet composition of the buzzard (Buteo buteo, L. 1758) in northern Spain]. Doñana Acta Vertebrata 12: 51-62. [in Spanish]

Butet A, Michel N, Rantier Y, Comor V, Hubert-Moy L, Nabucet J \& Delettre YR 2010: Responses of common buzzard (Buteo buteo) and Eurasian kestrel (Falco tinnunculus) to land use changes in agricultural landscapes of Western France Agriculture. Ecosystems \& Environment 138: 152-159.

Cramp S \& Simmons KEL 1980: Handbook of the birds of Europe, the Middle East, and North Africa: The Birds of the Western Palearctic. Vol. II. Oxford University Press, London, 696.

Debrot S, Fivaz G, Mermod C \& Weber JM 1982: Atlas des poils de mammiferes d'Europe. Institute of Zoology of University of Neuchatel, Neuchatel, 208.

Dementjev GP 1951: Sarych ili kanjuk (Buteo buteo) [Common buzzard (Buteo buteo)], 198-203. In: Dementjev GP \& Gladkov NA (eds), Ptitsy Sovetskogo Sojuza [Birds of USSR]. Vol. I. Sovetskaya Nauka, Moscow, 652. [In Russian]

Goszczyński J \& Piłatowski T 1986: Diet of common buzzards (Buteo buteo L.) and goshawks (Accipiter gentilis L.) in the nesting period. Ekologia Polska 34: 655-667.

Golodushko BZ 1965: Hischnyje ptitsy i ih rol' v ohotnichjem hoziajstve Beloveghskoj Puschi [Birds of prey and their role in forest economy of Białowieża forest]. PhD-thesis. Belarusian State University named after V.I. Lenin. Minsk, 21. [In Russian]

Graham IM, Redpath SM \& Thirgood SJ 1995: The diet and breeding density of common buzzards Buteo buteo in relation to indices of prey abundance. Bird Study 42: 165-173. DOI: 10.1080/0006365 9509477162

Holdsworth M 1971: Breeding biology of buzzards at Sedbergh during 1937-67. British Birds 60 (10): 412-420.

Jacobs J 1974: Quantitative measurements of food selection: a modification of the forage ratio and Ivlev's electivity index. Oecologia 14: 413-417. 
Jędrzejewska B \& Jędrzejewski W 1998: Predation in vertebrate communities. The Białowieza primeral forest as a case study. Springer, Berlin, 450.

Jędrzejewski W, Szymura A \& Jędrzejewska B 1994: Reproduction and food of the buzzard Buteo buteo in relation to the abundance of rodents and birds in Białowieża National Park, Poland. Ethology, Ecology \& Evolution 6: 179-190.

Karyakin IV 1998: Pernatyje hischniki Ural'skogo regiona. Sokoloobraznyje (Falconiformes) I sovoobraznyje (Strigiformes) [Raptors of Ural region. Falconiformes and Strigiformes]. Centre of Field Studies of Ural Animal Protection Union, Perm, 483. [In Russian]

Krebs CJ 1999: Ecological methodology. Addison-Welsey Educational Publishers, Menlo Park, California, 624.

Levins R 1968: Evolution in changing environments. Princeton University Press, Princeton, 132.

Mañosa S \& Pedro C 1992: Seasonal and sexual variation in the diet of the common buzzard in Northeastern Spain. Journal of Raptor Research 26: 235-238.

Mañosa S \& Cordero PJ 1992: Seasonal and sexual variation in the diet of the common buzzard in northeastern Spain. Journal of Raptor Reserch 26: 235-238.

März R 1987: Prey remnants in pellets and scats of predators. Akademie Verlag, Berlin, 288. [in German]

Matveev AV, Gurski BN \& Levitskaja RI 1988: Rel'ef Belorussii [Relief in Belarus]. Nauka i Tehnika, Minsk, 233. [in Russian]

Moore NW 1957: The past and present status of the buzzard in the British isles. British Birds 50: 175-197.

Pinowski J \& Ryszkowski L 1962: The buzzard's versatility as a predator. British Birds 55: 470-475.

Pucek Z 1981: Keys to vertebrates of Poland. Mammals. Polish Scientific Publishers, Warsaw, 367.

Redinov KA 2012: Trophic links of the buzzard in Ukraine, 155-168. In: Mel'nikov VN (ed.) Buzzards of northern Eurasia: distribution, population trends, biology. Centr-Print, Krivoj Rog, 272.

Reif V, Jungell S, Korpimäki E, Tornberg R \& Mycrä S 2004: Numerical response of common buzzards and predation rate of main and alternative prey under fluctuating food conditions. Annales Zoologici Fennici 41: 599-607.
Rooney E \& Montgomery WI 2013: Diet diversity of the common buzzard (Buteo buteo) in a vole-less environment. Bird Study 60: 147-155.

Selås V, Tveiten R \& Aanonsen OM 2007: Diet of common buzzards (Buteo buteo) in southern Norway determined from prey remains and video recordings. Ornis Fennica 84: 97-104. DOI: 10.1080/ 00063657.2013 .772085

Sergio F \& Hiraldo F 2008: Intraguild predation in raptor assemblages: a review. Ibis 150: 132-145.

Shalabaev RN \& Kassal BU 2010: Specific features of common buzzard (Buteo buteo) diet in different geographic and climatic zones. Omsk Biological School 7: 72-83. [In Russian]

Sidorovich VE 2011: Analysis of vertebrate predatorprey community. Tesey, Minsk, 736.

Sidorovich AA 2015: Metodologija issledovanija pozvonochnyh hischnikov: izuchenije pitanija [Methodology of a study of vertebrate predators: dietary investigation]. Belarusian State University, Minsk, 88. [in Russian]

Sokal RR, \& Rohlf FJ 1995: Biometry: The principles and practice of statistics in biological research. W.H. Freeman and company, New York, 887.

Šotnár K \& Obuch J 2009: Feeding ecology of a nesting population of the common buzzard (Buteo buteo) in the Upper Nitra region, Central Slovakia. Slovak Raptor Journal 3: 13-20. DOI: 10.2478/v10262-0120028-0

Spidsø TK \& Selås V 1988: Prey selection and breeding success in the common buzzard Buteo buteo in relation to small rodent cycles in southern Norway. Fauna Norvegica 11: 61-66.

Swann G 2011: Spatial variation in the breeding success of the common buzzard Buteo buteo in relation to habitat type and diet. MSc-thesis. Imperial College, London, 61.

Sylven M 1982: Reproduction and survival in common buzzards (Buteo buteo) illustrated by the seasonal allocation of energy expenses. PhD-thesis. University of Lund, Lund, 102.

Tapia L, Domínguez J \& Romeu M 2007: Diet of Common Buzzard (Buteo buteo) in Northwestern Spain as assessed by direct observation from blinds. Nova Acta Cientifica Compostelana 16: 145-149.

Teerink BJ 1991: Hair of West-European mammals. Cambridge Univ. Press, Cambridge, 224.

Truszkowski J 1976: Role of the common buzzard (Buteo buteo L.) in agrocenoses of the Middle Wielko- 
polska. Polish Ecological Studies 2: 103-111.

Wiener JG \& Smith MH 1972: Relative efficiencies of four small mammals' traps. Journal of Mammology 53: 868-873.

Zawadzka D, Zawadzki J \& Skubis L 2002: Skład pokarmu myszołowa Buteo buteo $\mathrm{w}$ gradiencie lesistości na Suwalszczyźnie [Diet composition of the buzzard Buteo buteo in a gradient of forest cover in Suwalszczyźna]. Notatki Ornitologiczne 43: 9-19. [In Polish with English summary]

Zuberogoitia I, Martínez JE, Martínez JA, Zabala J, Calvo JF, Castillo I, Azkona A, Irate A \& Hidalgo S 2006: Influence of management practices on nest site habitat selection, breeding and diet of the common buzzard Buteo buteo in two different areas of Spain. Ardeola 53: 83-98. 